\title{
Phosphatidylinositol Kinase
}

\section{A COMPONENT OF THE CHROMAFFIN-GRANULE MEMBRANE}

\author{
By JOHN H. PHILLIPS \\ Medical Research Council Laboratory of Molecular Biology, Hills Road, Cambridge CB2 2QH, U.K.
}

(Received 7 May 1973)

\begin{abstract}
Phosphorylation of bovine chromaffin granules by ATP leads to the formation of diphosphoinositide in the granule membrane. Both phosphatidylinositol kinase and its substrate are components of this membrane, and triphosphoinositide is not formed under the conditions of the assay. The reaction is $\mathrm{Mg}^{2+}$-dependent and is stimulated by $\mathrm{Mn}^{2+}$ and $\mathrm{F}^{-}$ions. The initial reaction is rapid, with a broad $\mathrm{pH}$ profile and a 'transition' temperature for its activation energy at $27^{\circ} \mathrm{C}$. The apparent $K_{m}$ for ATP is $5 \mu \mathrm{M}$. ADP, $N$-ethylmaleimide, $\mathrm{Cu}^{2+}$ ions and $\mathrm{NaIO}_{4}$ are inhibitory. The phospholipids of chromaffin-granule membranes have been analysed: $6.8 \%$ of the lipid $P$ is found in phosphatidylinositol, and only $2-3 \%$ in phosphatidylserine. Comparison of the rate of phosphorylation of intact and lysed granules suggests that the sites for phosphorylation are on the outer (cytoplasmic) surface of the granules, and diphosphoinositide may therefore make an important contribution to the charge of the chromaffin granule in vivo.
\end{abstract}

The adrenal medulla, an endocrine gland derived from the sympathetic nervous system, is a convenient source of secretory vesicles. These, the chromaffin granules, are very abundant and, because of their high density, are easily purified. The membrane-bound granules, about $200 \mathrm{~nm}$ in diameter, have a high content of protein, of catecholamines, and of ATP, which are released by hypo-osmotic lysis. Kirshner (1972) has reviewed the biology of the adrenal medulla and studies on isolated chromaffin granules.

Trifaró \& Dworkind (1971) reported the phosphorylation in vitro of the membrane of the chromaffin granule, and a major product of this reaction has been identified as diphosphoinositide (Buckley et al., 1971). In the present paper some properties of the phosphatidylinositol kinase, a membrane component that utilizes a substrate within the same phospholipid bilayer, are described. This enzyme has previously been reported as a component of the plasma membrane and of the microsomal fraction of rat liver and other tissues (Harwood \& Hawthorne, 1969); Buckley \& Hawthorne (1972) have shown that ATP phosphorylates erythrocyte membranes to yield polyphosphoinositides which greatly increases their calciumbinding capacity.

\section{Experimental}

\section{Materials}

[ $\gamma_{-}{ }^{32}$ P]ATP was synthesized by the method of Glynn \& Chappell (1964) with enzymes purchased from the Boehringer Corp. (London) Ltd., London W.5, U.K. It was purified on a column $(1.4 \times 0.5 \mathrm{~cm})$ of Dowex AG1 (X10, $\mathrm{Cl}^{-}$form) and stored frozen as the $\mathrm{NH}_{4}{ }^{+}$salt after neutralization with a chloroform solution of tri-n-octylamine (A. Travers, personal communication). ATP and ADP concentrations were measured spectrophotometrically.

In general, solutions were buffered with Hepes.* Pipes buffer was also used, and these were obtained from BDH Chemicals Ltd., Poole, Dorset, U.K. MR63 [bis-(4-allyldimethylammoniumphenyl)pentan-3-one dibromide] is a specific acetylcholinesterase inhibitor obtained from Wellcome Reagents Ltd., Beckenham, Kent, U.K. Radiochemicals were obtained from The Radiochemical Centre, Amersham, Bucks., U.K., and silica gel was grade $\mathbf{H}$ from E. Merck A.-G., Darmstadt, Germany. Phospholipid standards were from Koch-Light Laboratories Ltd., Colnbrook, Bucks., U.K., and other biochemicals were from Sigma (London) Chemical Co. Ltd., Kingston-upon-Thames, Surrey, U.K. ${ }^{32}$ P-labelled nematode RNA was kindly supplied by Dr. J. Sulston (of this Laboratory).

\section{Methods}

Fractionation of the adrenal medulla. Bovine adrenal medullae (usually six to twelve per preparation) were cooled on ice and used within $1 \mathrm{~h}$ of slaughter. After mincing and homogenization in $0.3 \mathrm{M}$-sucrose containing $10 \mathrm{~mm}$-Hepes buffer, $\mathrm{pH} 7.2$ (the pH of the buffer was adjusted with $1 \mathrm{M}-\mathrm{NaOH}$;

* Abbreviations: Hepes, 2-(N-2-hydroxyethylpiperazin$N^{\prime}$-yl)ethanesulphonic acid; Pipes, piperazine- $N N^{\prime}$. bis-(2-ethanesulphonic acid); ATPase, adenosine triphosphatase.

Vol. 136 
this solution is referred to as 'buffered sucrose'), the extract was centrifuged at $1000 \mathrm{~g}$ for $10 \mathrm{~min}$ at $4^{\circ} \mathrm{C}$. The pellet, suspended in buffered sucrose, was filtered through two layers of gauze to give a nuclear fraction. The supernatant was centrifuged at $27000 \mathrm{~g}$ for $20 \mathrm{~min}$ at $4^{\circ} \mathrm{C}$. The resulting supernatant was used for preparation of the microsomal fraction. The upper layer of the pellet was removed by washing and suspension in buffered sucrose to give a mitochondrial fraction (Kirshner, 1962). The remaining pellet was resuspended and re-centrifuged. Washings from the pellet were added to those recovered previously, and the remaining pellet was suspended in buffered sucrose to give a crude granule fraction.

The $27000 \mathrm{~g}$ supernatant was centrifuged for $1 \mathrm{~h}$ at $4^{\circ} \mathrm{C}$ and $150000 \mathrm{~g}$. The post-microsomal supernatant was saved for assay, and the microsomal pellet was washed as follows: (1) in $0.15 \mathrm{M}-\mathrm{NaCl}$ containing $10 \mathrm{~mm}$-Hepes, $\mathrm{pH} 7.2$; (2) in $1.0 \mathrm{M}-\mathrm{NaCl}$ containing $10 \mathrm{~mm}$-Hepes; (3) in $0.2 \mathrm{M}-\mathrm{NaHCO}_{3}, \mathrm{pH} \mathrm{8.0}$; and (4) in $0.075 \%$ sodium deoxycholate. The final pellet (microsomal membranes) was suspended in buffered sucrose. This method is based on that of Meldolesi et al. (1971) and some properties of a similar preparation have been described by Weihing et al. (1972).

The crude granule fraction was purified by centrifugation through $1.6 \mathrm{M}$-buffered sucrose, as described by Smith \& Winkler (1967). Purified chromaffin granules were lysed by suspension in $10 \mathrm{~mm}-\mathrm{KCl}$ containing $10 \mathrm{~mm}-\mathrm{Hepes}, \mathrm{pH} 7.2$; the membranes were collected by centrifugation $\left(45 \mathrm{~min}\right.$ at $4^{\circ} \mathrm{C}$ and $150000 \mathrm{~g})$ and suspended in $1.6 \mathrm{M}$-sucrose $(0.8 \mathrm{M}$ in some experiments). After $5 \mathrm{~min}$ at $0^{\circ} \mathrm{C}$, they were relysed by dilution and re-centrifuged. This cycle was repeated twice. The final chromaffin-granule-membrane pellet was suspended in buffered sucrose. Fractions were stored at $-20^{\circ} \mathrm{C}$.

Sucrose density gradients were centrifuged for $3 \mathrm{~h}$ at $4^{\circ} \mathrm{C}$ and $48000 \mathrm{rev}$./min in a Spinco SW50L rotor $(200000 \mathrm{~g})$. Sucrose concentrations were checked by refractive index measurements of all fractions collected.

Enzyme assays. Phosphatidylinositol kinase was assayed as follows: incubations were carried out in conical glass tubes in media containing $50 \mathrm{~mm}$-Hepes, pH 7.2, $5 \mathrm{~mm}-\mathrm{NaF}, 20 \mathrm{~mm}-\mathrm{MgCl}_{2}, 2 \mathrm{~mm}-\mathrm{MnCl}_{2}$ and $\left[\gamma_{-}{ }^{32} \mathrm{P}\right] \mathrm{ATP}$ of concentration and specificradioactivity as indicated in the legends to the figures. In experiments in which intact chromaffin granules were labelled (Table 1, and Figs. 1 and 8 ) the medium contained 20mm-Hepes, pH 7.2, 3 mM-NaF, 20mm$\mathrm{MgCl}_{2}, 1 \mathrm{mM}-\mathrm{MnCl}_{2}$ and $0.26 \mathrm{M}$-sucrose. Samples $(50 \mu \mathrm{l})$ usually contained about $5 \mu \mathrm{g}$ of membrane protein. Control incubations contained 2mM-EDTA instead of $\mathrm{Mg}^{2+}$ and $\mathrm{Mn}^{2+}$. After incubation the tubes were placed in ice and $0.1 \mathrm{ml}$ of $1 \mathrm{~mm}$-sodium phosphate, pH6.5, containing $1 \mathrm{~mm}$-ATP, was added, followed by $2 \mathrm{ml}$ of cold $10 \%$ (w/v) trichloro- acetic acid. The samples were filtered through $0.45 \mu \mathrm{m}$ Millipore filters which were washed with $5 \mathrm{ml}$ of $10 \%(w / v)$ trichloroacetic acid, dried and counted for radioactivity in a liquid-scintillation counter. In some experiments (Fig. 1) most radioactive ATP was removed by passing the granules through a column $(5.5 \mathrm{~cm} \times 0.5 \mathrm{~cm})$ of Sephadex G-50, equilibrated with buffered sucrose (or with $10 \mathrm{~mm}$-Hepes to produce hypo-osmotic lysis of the chromaffin granules), and collecting the void volume effluent.

Acetylcholinesterase was measured by a modification (R. L. Russell, personal communication) of the method of Potter (1967). Assays $(100 \mu \mathrm{l}, 10 \mathrm{~min}$ at $37^{\circ} \mathrm{C}$ ) contained $50 \mu \mathrm{M}-\left[\right.$ acetyl $\left.{ }^{3} \mathrm{H}\right]$ acetylcholine $(50 \mathrm{mCi} / \mathrm{mmol})$. Essentially all enzyme activity measured was inhibited by $100 \mu \mathrm{M}-\mathrm{MR} 63$, an inhibitor of acetylcholinesterase that does not affect other cholinesterases [see Wheeler et al. (1972) for use of a similar inhibitor]. Monoamine oxidase was assayed by the method of Wurtman \& Axelrod (1963): assays contained $0.1 \mathrm{M}-$ Hepes, $\mathrm{pH} 7.2$, and $40 \mu \mathrm{M}$ $\left[{ }^{14} \mathrm{C}\right]$ tyramine hydrochloride $(42 \mathrm{mCi} / \mathrm{mmol})$ in $100 \mu \mathrm{l}$ and were incubated for $15 \mathrm{~min}$ at $37^{\circ} \mathrm{C}$. Dopamine $\beta$-hydroxylase was assayed by a modification $(H$. B. Pollard, personal communication) of the method of Friedman \& Kaufman (1965): incubations $(100 \mu \mathrm{l})$ contained 100mm-potassium phosphate, pH6.5, $50 \mathrm{~mm}$-sodium fumarate, $\mathrm{pH} 6.5,0.5 \mathrm{~mm}$-ascorbic acid, $5 \mathrm{~mm}$-iproniazid phosphate, $0.1 \%$ Triton X-100, $1 \%$ ethanol, 830 Sigma units of catalase and $23 \mu \mathrm{M}$ $\left[{ }^{14} \mathrm{C}\right]$ tyramine $(42 \mathrm{mCi} / \mathrm{mmol})$. The reaction was terminated after $20 \mathrm{~min}$ at $37^{\circ} \mathrm{C}$. The assays in Table 1 were in the presence of $10 \mu \mathrm{M}$-sodium $p$-hydroxymercuribenzoate (Duch et al., 1968) to inactivate endogenous inhibitor. Glucose 6-phosphatase was assayed in the presence of $50 \mathrm{~mm}$-sodium maleate, pH6.0, 2mM-EDTA, $2 \mathrm{~mm}-\mathrm{KF}$ and $28 \mathrm{~mm}$-glucose 6-phosphate (Hübscher \& West, 1965) in $100 \mu l$, for $15 \mathrm{~min}$ at $37^{\circ} \mathrm{C}$. The phosphate liberated was estimated by the method of Post \& Sen (1967). Acid ribonuclease was assayed by digestion of ${ }^{32} \mathrm{P}$-labelled nematode RNA (approx. $8 \mu \mathrm{g} / \mathrm{ml}, 2.5 \times 10^{4}$ c.p.m. $/ \mu \mathrm{g}$ ) in $100 \mu \mathrm{l}$ of $0.1 \mathrm{M}$-sodium acetate buffer, $\mathrm{pH} 4.6$, for $15 \mathrm{~min}$ at $37^{\circ} \mathrm{C}$. The reaction was stopped by precipitation with $5 \%(w / v)$ trichloroacetic acid, followed by Millipore filtration. Protein was estimated by the method of Lowry et al. (1951) with crystalline bovine serum albumin as a standard. Catecholamines were estimated by the method of von Euler \& Hamberg (1950).

Phospholipid assays. Subcellular fractions were extracted for several minutes with 15-20 volumes of chloroform-methanol $(2: 1, \mathrm{v} / \mathrm{v})$. Extracts were washed with $0.1 \mathrm{M}-\mathrm{KCl}$ equilibrated with chloroformmethanol (Folch et al., 1957). Phospholipids were separated by t.l.c. on $\left(\mathrm{NH}_{4}\right)_{2} \mathrm{SO}_{4}$-impregnated Silica Gel H (Kaulen, 1972) and phosphate analyses were performed by the method of McClare (1971). 
Diphosphoinositide was assayed as follows: fractions were made $0.7 \mathrm{M}$ with $\mathrm{HCl}$ and extracted with $2 \mathrm{vol}$. of chloroform-methanol $(2: 1, \mathrm{v} / \mathrm{v})$ containing $0.25 \%$ conc. $\mathrm{HCl}$. Phosphoinositides were then separated by t.l.c. on oxalate-impregnated silica gel H (Gonzalez-Sastre \& Folch-Pi, 1968). Both solvent systems of these authors were used. After a phos- phorylation assay of membranes, non-radioactive ATP and sodium phosphate $(2.5 \mathrm{~mm}$ each) were added to the incubation mix which was then dialysed against $10 \mathrm{~mm}-\mathrm{Tris}-\mathrm{HCl}, \mathrm{pH} 7.4$, overnight. The material was then passed down a column $(5.5 \mathrm{~cm} \times$ $0.5 \mathrm{~cm}$ ) of Sephadex G-50, equilibrated with $10 \mathrm{~mm}-$ Hepes, pH 7.2, and excluded material was collected.

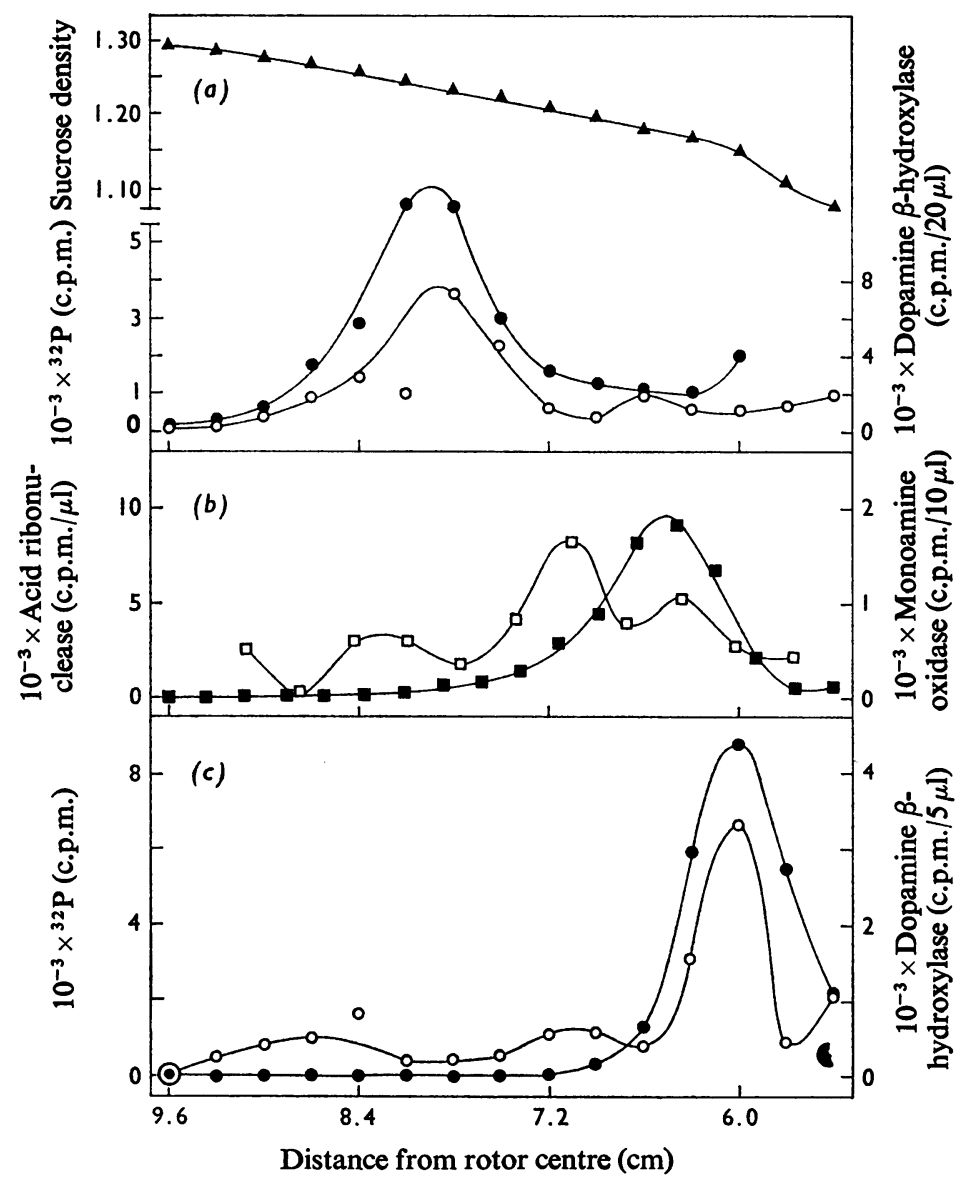

Fig. 1. Sucrose density gradients of crude granule fraction from adrenal medulla

Crude granule fraction $\left(100 \mu \mathrm{l}, 3.3 \mathrm{mg}\right.$ of protein) was phosphorylated in the presence of $40 \mu \mathrm{M}-\left[\gamma-{ }^{32} \mathrm{P}\right] \mathrm{ATP}$ $\left(4.7 \times 10^{5}\right.$ c.p.m. $\left./ \mathrm{nmol}\right)$ for $1 \frac{1}{2} \mathrm{~min}$ at $37^{\circ} \mathrm{C}$. One portion was passed down an iso-osmotic Sephadex G-50 column, collected in buffered sucrose, and applied $(0.3 \mathrm{ml})$ to the sucrose density gradient $(a)$. Two gradients of crude granule fraction $(b)$ were used for assay of mitochondrial and lysosomal markers: the shapes of the gradients were as shown in $(a)(\Lambda)$. Another portion of the phosphorylated crude granule fraction was lysed by passage down a hypo-osmotic Sephadex G-50 column and collected in 10mM-Hepes, pH 7.2. Its sucrose concentration was adjusted to $0.3 \mathrm{M}$ and it was applied to the sucrose density gradient $(c)$, which was identical with $(a)$. Portions of fractions from (a) and (c) $(20 \mu \mathrm{l}$ and $5 \mu \mathrm{l}$ respectively) were removed for assay of dopamine $\beta$-hydroxylase (O). The remainder of each fraction was diluted with water and assayed directly for ${ }^{32} \mathrm{P}$ after addition of Bray's (1960) scintillation fluid ( $\bullet$ ). Monoamine oxidase $(\square)$ and acid ribonuclease $(\square)$ were measured on $10 \mu l$ and $1 \mu l$ samples respectively. 
In some experiments, dialysis was omitted. The radioactive membranes were extracted and chromatographed, portions of the silica-gel absorbent being counted directly in toluene scintillation fluid containing 2,5-diphenyloxazole $(5 \mathrm{~g} / \mathrm{l})$ and 1,4-bis-(5phenyloxazol-2-yl)benzene $(0.3 \mathrm{~g} / \mathrm{l})$.

\section{Results}

Identification of phosphatidylinositol kinase as a component of the chromaffin granule

Short incubations of a crude large-granule fraction from the adrenal medulla with $\left[\gamma^{32}\right.$ P]ATP led to incorporation of radioactivity into particulate material. Such phosphorylated material was subjected to isopycnic centrifugation on a sucrose gradient (Fig. 1a). Radioactivity was found in the region of the gradient containing chromaffin granules, identified by the presence of dopamine $\beta$-hydroxylase, a component of both the interior of the granule and of its membrane (Winkler et al., 1970). Monoamine oxidase and acid ribonuclease activities, used as markers of mitochondria and lysosomes, and assayed on other gradients, are shown for comparison (Fig. 1b). If, however, the phosphorylated granule fraction was subjected to hypo-osmotic lysis before centrifugation, both the dopamine $\beta$-hydroxylase activity and the incorporated ${ }^{32} \mathrm{P}$ were found at the top of the gradient, in the free membrane region (Fig. 1c).
Membranes of purified chromaffin granules may be obtained by lysis produced by a cycle of hypo- and hyper-osmotic shock treatments (H. B. Pollard, personal communication). Although catecholamines are readily released by osmotic shock, it is difficult to remove all traces of the proteins found within the granules, the chromogranins, and it is therefore difficult to obtain consistent specific activities for membranes from one preparation to another. The preparation is slightly contaminated with mitochondria and mitochondrial membranes. Fig. 2 shows a flotation gradient of a granule membrane fraction. This procedure separates granule membranes from the mitochondrial outer membranes and intact mitochondria which are present as contaminants. Incorporation of phosphate from $\left[\gamma-{ }^{32} \mathrm{P}\right] \mathrm{ATP}$ clearly follows the dopamine $\beta$-hydroxylase activity. In other words, both the substrate for phosphorylation and the kinase are present in the band of chromaffin granule membranes.

Such experiments do not conclusively eliminate the possibility that the incorporation is due to contamination from plasma membrane fragments. However, comparison of activities in several subcellular fractions from the adrenal medulla (Table 1) make this very unlikely. Particulate acetylcholinesterase has been used as a marker for the plasma membrane (Wheeler et al., 1972) as the high activity of phosphatases and ATPases in the adrenal medulla

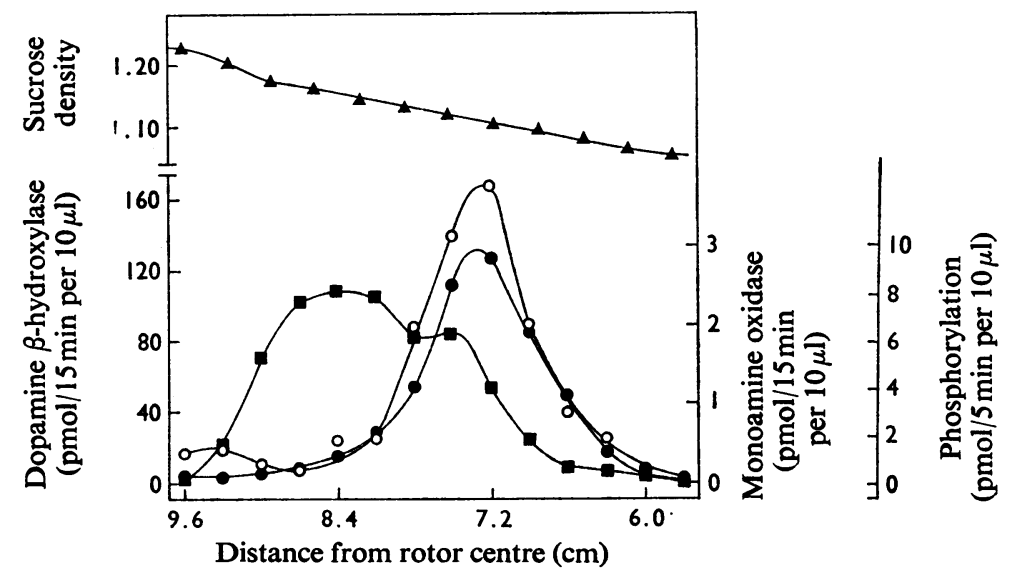

Fig. 2. Flotation gradient of purified chromaffin granule membranes

The membranes $(0.5 \mathrm{mg}$ of protein) were suspended in $1.87 \mathrm{M}$-sucrose containing $10 \mathrm{~mm}$-Hepes, $\mathrm{pH} 7.2 ; 0.4 \mathrm{ml}$ of membrane suspension was overlaid with a gradient of sucrose in $10 \mathrm{mM}-\mathrm{Hepes}$ as shown $(\Delta)$. After centrifugation, portions $(25 \mu \mathrm{l})$ of each fraction were removed for phosphorylation $\left(21 \mu \mathrm{M}-\left[\gamma-{ }^{32} \mathrm{P}\right] \mathrm{ATP}, 1.5 \times 10^{5} \mathrm{c} . \mathrm{p} . \mathrm{m}\right.$. $/ \mathrm{nmol}$, $5 \mathrm{~min}$ at $\left.37^{\circ} \mathrm{C}\right)(\bullet)$. Portions $(10 \mu \mathrm{l})$ were assayed for dopamine $\beta$-hydroxylase $(0)$, and portions $(30 \mu \mathrm{l})$ for monoamine oxidase ( $(\mathbf{})$. 


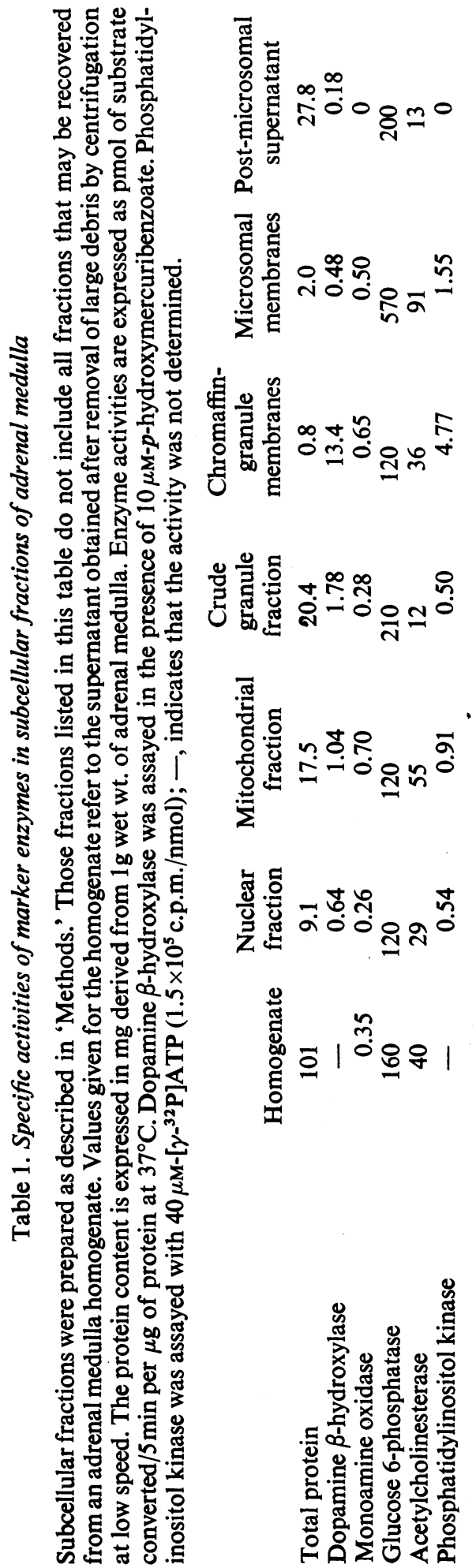

make $5^{\prime}$-nucleotidase, $\mathrm{K}^{+}$-stimulated phosphatase and $\mathrm{Na}^{+}, \mathrm{K}^{+}$-stimulated ATPase activities difficult to measure.

The incorporation of ${ }^{32} \mathrm{P}$ into several subcellular fractions other than the chromaffin-granule fractions is presumably correlated with the presence of phosphorylating enzymes in the plasma membrane and/or the endoplasmic reticulum; kinase and acetylcholinesterase activities are found in similar proportions and are especially rich in the mitochondrial fraction and in microsomal membranes. The low dopamine $\beta$-hydroxylase activity in such fractions rules out contamination by phosphorylation activity of the chromaffin granules.

\section{Identification of the product of phosphorylation}

Dialysis of phosphorylated chromaffin granule membranes removed most $\left[{ }^{32} \mathrm{P}\right] \mathrm{ATP}$ and removal was almost quantitative after gel filtration of the dialysed material on Sephadex G-50. After acidification, material was extracted with chloroformmethanol $(2: 1, \mathrm{v} / \mathrm{v})$ containing $0.25 \% \mathrm{HCl}$. About $80 \%$ of the residual radioactivity was generally extracted; another $10-20 \%$ could be removed by one further extraction of the aqueous phase. These results agree with those of Buckley et al. (1971). T.1.c. on oxalic acid-impregnated plates (Gonzalez-Sastre \& Folch-Pi, 1968) showed that diphosphoinositide was the major product; less than $5 \%$ of the counts were trailing behind this spot, with less than $2 \%$ in the triphosphoinositide region. A small radioactive region at the origin was attributed to $\left[{ }^{32} \mathrm{P}\right] \mathrm{ATP}$.

No radioactive protein bands were found when phosphorylated material was subjected to electrophoresis on sodium dodecyl sulphate-polyacrylamide gels. A diffuse region of radioactivity was found in the gel ahead of the tracker dye, where phospholipids are expected to migrate.

\section{Conditions of the reaction}

The enzyme appears to be a typical kinase: Fig. 3 shows data for $\mathrm{Mg}^{2+}$ ion dependence obtained in solutions of low and high ionic strength, conditions that are used in catecholamine uptake (Kirshner, 1962) and release (Poisner \& Trifaró, 1967) experiments in vitro. Both $\mathrm{Mn}^{2+}$ ions and $\mathrm{NaF}$ stimulate the reaction by about $50 \%$ in the presence of $\mathrm{Mg}^{2+}$ (optimal concentrations $2 \mathrm{mM}-\mathrm{Mn}^{2+}$ and $4 \mathrm{mM}-\mathrm{NaF}$ ). $\mathrm{Ca}^{2+}$ is somewhat inhibitory at concentrations higher than $5 \mathrm{~mm}$. Monovalent cations have little effect (at concentrations up to $150 \mathrm{~mm}$ ). The phosphorylated membrane preparation is quite stable when incubated in the absence of ATP. The microsomal membrane preparation, however, which has generally similar ion requirements, contains considerable phosphatase activity, and incorporation into this fraction is 


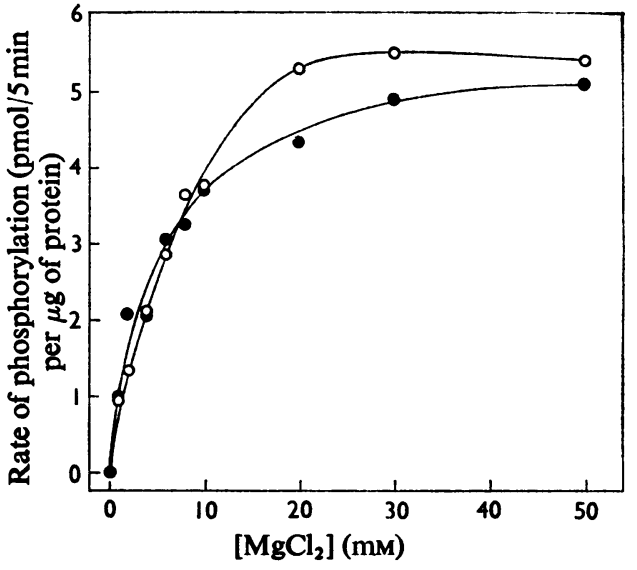

Fig. 3. $\mathrm{Mg}^{2+}$ requirements for phosphatidylinositol kinase

Chromaffin-granule membranes $(94 \mu \mathrm{g}$ of protein $/ \mathrm{ml})$ were phosphorylated in the presence of $35 \mu \mathrm{M}-\left[\gamma-{ }^{32} \mathrm{P}\right]$ ATP $\left(1.75 \times 10^{5}\right.$ c.p.m. $\left./ \mathrm{nmol}\right)$ for $5 \mathrm{~min}$ at $37^{\circ} \mathrm{C}$. The medium contained $0.24 \mathrm{M}$-sucrose and $30 \mathrm{~mm}$-Hepes, $\mathrm{pH} 7.2(\bullet)$, or $0.15 \mathrm{M}-\mathrm{KCl}, 4 \mathrm{~mm}-\mathrm{NaCl}$ and $16 \mathrm{~mm}-$ Hepes, pH7.2 (O).

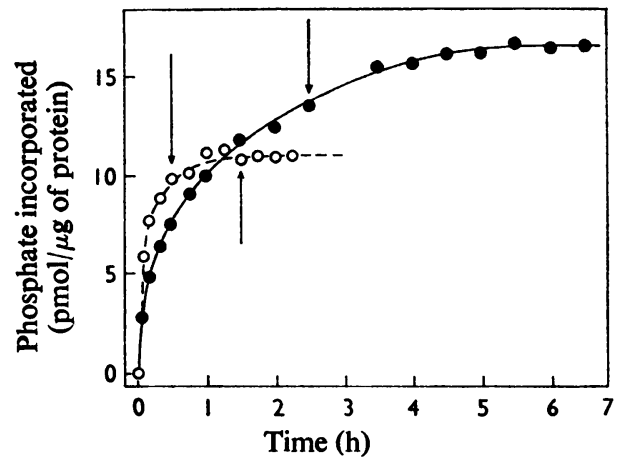

Fig. 4. Kinetics of chromaffin-granule membrane phosphorylation

Standard incubation mix (pH7.2) containing $130 \mu \mathrm{g}$ of membrane protein $/ \mathrm{ml}(\bullet)$. At the start of incubation $\left(37^{\circ} \mathrm{C}\right)$ the $\left[\gamma_{-}{ }^{32} \mathrm{P}\right] \mathrm{ATP}$ concentration was $45 \mu \mathrm{M}$ $\left(5.5 \times 10^{4}\right.$ c.p.m./nmol); additions were made after $\frac{1}{2}$ and $2 \frac{1}{2} \mathrm{~h}$ (arrows) to bring the total added concentration to $90 \mu \mathrm{M}$ and $135 \mu \mathrm{M}$. In another incubation, Hepes buffer was replaced by $10 \mathrm{~mm}$-sodium acetate buffer, pH4.9 (O); the membrane concentration was $94 \mu \mathrm{g}$ of protein $/ \mathrm{ml}$ and the $\left[\gamma^{-32} \mathrm{P}\right] \mathrm{ATP}\left(1.28 \times 10^{5}\right.$ c.p.m./nmol) concentration was $45 \mu \mathrm{M}$, with additions being made after $\frac{1}{2}$ and $1 \frac{1}{2} \mathrm{~h}$, as above. Control experiments were performed in the presence of 2.5 mM-EDTA, and these values were subtracted.

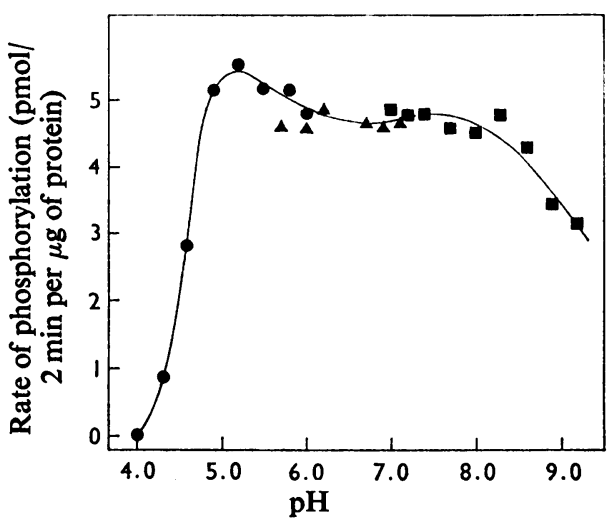

Fig. 5. pH profile for phosphatidylinositol kinase of chromaffin-granule membranes

Incubation mixes were preincubated at $37^{\circ} \mathrm{C}$ and the reaction was started by the addition of a membrane suspension at the same temperature. Incubation was continued for $2 \mathrm{~min}$. Final concentrations were: chromaffin-granule membranes, $94 \mu \mathrm{g}$ of protein $/ \mathrm{ml}$ and $\left[\gamma^{32} \mathrm{P}\right]$ ATP $\left(2.6 \times 10^{5}\right.$ c.p.m. $\left./ \mathrm{nmol}\right), 33 \mu \mathrm{M}$. Ionic concentrations were as usual. Buffers used were $50 \mathrm{~mm}$-sodium acetate $(\bullet), 50 \mathrm{~mm}$-Pipes $(\triangle)$ or $50 \mathrm{~mm}-$ Hepes (匹).

greatly stimulated by $\mathrm{NaF}(120 \%$ stimulation by $10 \mathrm{~mm})$.

The kinetics of phosphorylation at $\mathrm{pH} 7.2$ and $37^{\circ} \mathrm{C}$ are shown in Fig. 4. There is a very rapid initial phase, followed by a long slow period of incorporation. Extra ATP was added during this experiment as chromaffin-granule membranes contain an active $\mathrm{Mg}^{2+}$-stimulated ATPase (Banks, 1965). At low pH, however, the rapid initial phase is not followed by a slow incorporation; the incorporation ceases after $1 \mathrm{~h}$ (Fig. 4). The reaction is far from linear: initial velocities were obtained from $2 \mathrm{~min}$, or slightly less accurately from $5 \mathrm{~min}$ incubations. It is possible that product inhibition causes the rapid slowing of the reaction, but this cannot be studied with the enzyme in situ in the membrane.

The $\mathrm{pH}$ profile for the reaction is very broad (Fig. 5). Phosphorylation of the microsomal membrane fraction is very similar. The profile appears to be almost bimodal, and this effect is accentuated if, for example, $5 \mathrm{~min}$ incubations are used to obtain approximations of the initial velocities because of the non-linear kinetics. However, ionic requirements for chromaffin granule membrane phosphorylation are essentially the same at pH4.9 and 7.7; the apparent $K_{m}$ for ATP is also the same at these two $\mathrm{pH}$ values. The product of the reaction was checked after both short and long times of phosphorylation (15 min and $4 \mathrm{~h}$ ) at $\mathrm{pH} 5$ 
and 7 , and in the presence and absence of $\mathrm{NaF}$. Diphosphoinositide was the only product in all cases. The broad pH profile is not a consequence of the presence of two different enzymes in the membrane using different pools of phosphatidylinositol. Experiments in which the pH of the incubation medium is changed after the initial rapid incorporation do not reveal a new rapid phase of diphosphoinositide synthesis. After the pH change the reaction follows the course expected for the new $\mathrm{pH}$ value.

An Arrhenius plot for the reaction is shown in Fig. 6. A change in activation energy occurs at $27^{\circ} \mathrm{C}$; similar changes have been shown for many membranebound mitochondrial enzymes (Stekhoven et al., 1971). This change does not occur at the same temperature as that found for the chromaffin-granule membrane ATPase $\left(32^{\circ} \mathrm{C} ; \mathrm{H}\right.$. B. Pollard, personal communication). It presumably reflects a conformational change of the enzyme (see the Discussion section).

The apparent $K_{m}$ for ATP is $5 \mu \mathrm{M}$ (Fig. 7). ADP, $N$-ethylmaleimide, $\mathrm{Cu}^{2+}$ ions and $\mathrm{NaIO}_{4}$ are potent inhibitors: phosphorylation is inhibited by $50 \%$ by preincubating chromaffin-granule membranes for

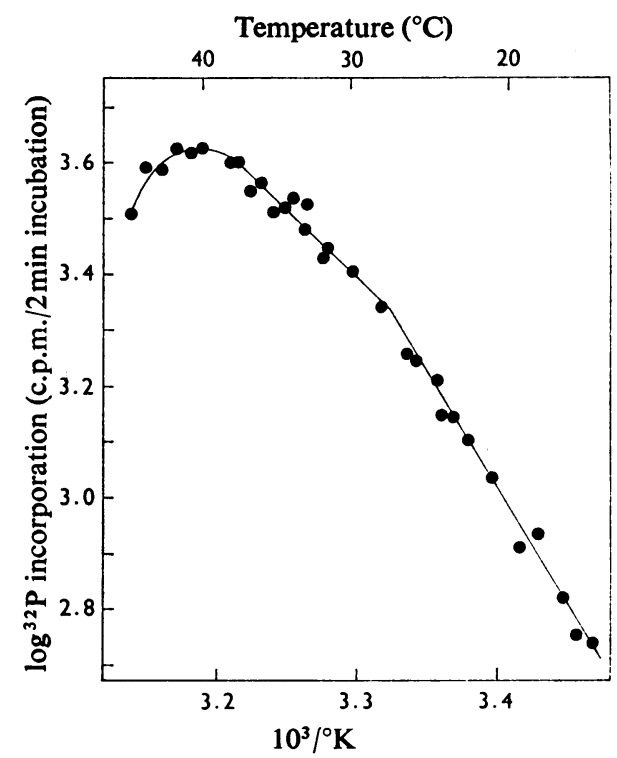

Fig. 6. Arrhenius plot for chromaffin-granule membrane phosphorylation

Membranes $(130 \mu \mathrm{g}$ of protein $/ \mathrm{ml})$ were incubated under standard conditions with $7.8 \mu \mathrm{M}-\left[\gamma_{-}{ }^{32} \mathrm{P}\right] \mathrm{ATP}$ $\left(4.6 \times 10^{5}\right.$ c.p.m. $\left./ \mathrm{nmol}\right)$. All solutions were prewarmed to the required temperature and the reaction, started by addition of the membrane suspension, was continued for $2 \mathrm{~min}$.

$10 \mathrm{~min}$ at $25^{\circ} \mathrm{C}, \mathrm{pH} 7.2$, with $200 \mu \mathrm{M}-N$-ethylmaleimide, or for $5 \mathrm{~min}$ with $25 \mu \mathrm{M}-\mathrm{NaIO}_{4} \cdot \mathrm{CuCl}_{2}(12.5 \mu \mathrm{M})$ also inhibits the phosphorylation by $50 \%$. Ionic detergents (sodium deoxycholate and sodium dodecyl

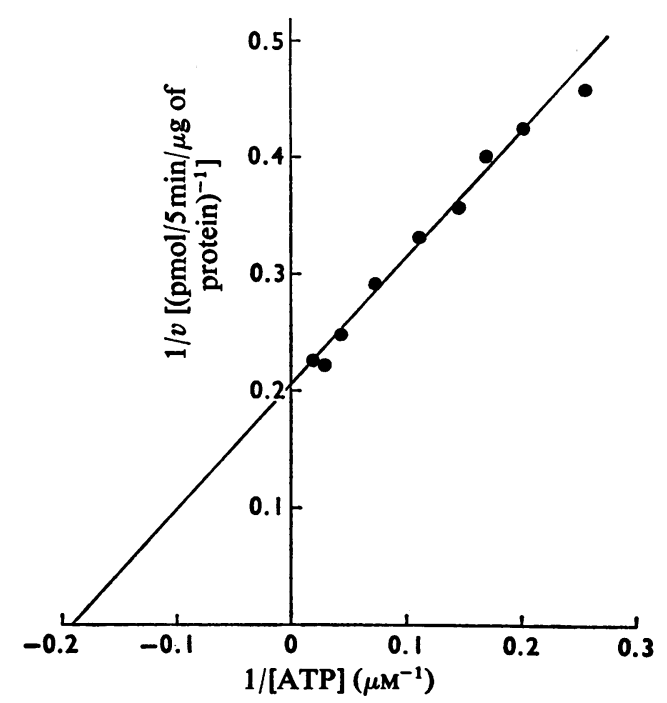

Fig. 7. Lineweaver-Burk plot for ATP dependence of chromaffin-granule-membrane phosphorylation

Membranes $(130 \mu \mathrm{g}$ of protein $/ \mathrm{ml})$ were incubated under standard conditions for $5 \mathrm{~min}$ at $37^{\circ} \mathrm{C}$.

\section{Table 2. Phospholipids of chromaffin-granule membranes}

Values represent the percentages of the total lipid $\mathbf{P}$ recovered from the chromatography plate and are means \pm S.E.M. in the present work, nine analyses were made of material from six preparations of membranes, by the method of Kaulen (1972). Polyphosphoinositides were estimated by the method of GonzalezSastre \& Folch-Pi (1968). The estimates of Blaschko et al. (1967), made by using a different method, are given for comparison.

Lysolecithin

Sphingomyelin

Lecithin

Phosphatidylinositol

Phosphatidylserine

Phosphatidylethanolamine

Front

Diphosphoinositide

Triphosphoinositide
Blaschko et al. Present (1967) work

$\left.\begin{array}{l}16.8 \pm 0.5 \\ 10.9 \pm 0.4\end{array}\right\} 23.0 \pm 1.2$

$26.0 \pm 0.6 \quad 30.2 \pm 1.6$

$9.2 \pm 0.7 \quad 6.8 \pm 0.5$

$36.1 \pm 1.138 .2 \pm 1.1$

$0.6 \pm 0.1 \quad 1.9 \pm 0.3$

$<0.1$ 
sulphate) are inhibitory, but Triton $\mathrm{X}-100$ is much less so. Cyclic AMP ( $50 \mathrm{nM}-0.5 \mathrm{~mm})$, reserpine $(5 \mu \mathrm{M})$ and ouabain $(0.2 \mathrm{mM})$ have no effect on the reaction.

\section{Phospholipids of the chromaffin-granule membrane}

The phospholipid composition of the chromaffin granule membrane preparations was investigated by t.l.c. of chloroform-methanol extracts by the method of Kaulen (1972). This method gives an excellent separation of phosphatidylinositol, which is otherwise difficult to obtain. Lysolecithin and sphingomyelin, however, are poorly separated, as are phosphatidylserine and phosphatidylethanolamine. The results may be compared with the analysis made by Blaschko et al. (1967) (Table 2). Phosphatidylinositol comprises $6.8 \%$ of the phospholipids, whereas phosphatidylserine appears to be present at a value of 2-3\%. Polyphosphoinositides cannot be detected.

The membrane preparation used in this work contains $1.29 \pm 0.08 \mu \mathrm{mol}$ of phospholipid/mg of protein (mean \pm S.E.M., nine determinations from five preparations). The preparation used for the experiment shown in Fig. 4 contained $80 \mathrm{nmol}$ of phosphatidylinositol/mg of protein. Approximately one-fifth of the phosphatidylinositol is therefore phosphorylated during the prolonged incubation, about half of this being within the first $30 \mathrm{~min}$ of the reaction.

\section{Sites of phosphorylation}

Are there sites for phosphorylation on both the outside and inside of the chromaffin-granule membrane? A preparation of the crude granule fraction was lysed by dialysis against dilute buffer: a control was dialysed against iso-osmotic sucrose. Granules lysed in this way are no longer competent to incorporate catecholamines in the assay of Kirshner (1962), although the control granules are unaffected. The rate of phosphorylation of each preparation was measured in an iso-osmotic medium; under these conditions ATP does not enter the intact granules (J. H. Phillips, unpublished work), nor is there significant lysis with release of unlabelled ATP. The rate of uptake of ${ }^{32} \mathrm{P}$ is the same in the granules before and after lysis (Fig. 8) which suggests that under these conditions the sites for phosphorylation are confined to the outer (i.e. cytoplasmic) surface of the granule membrane. The curves of Fig. 8 are non-linear, presumably because of the ATPase activity of the preparation.

The specific enzyme activity of the material in the experiment shown in Fig. 8 is $0.68 \mathrm{pmol} / 5 \mathrm{~min}$ per $\mu \mathrm{g}$ of protein. This compares with an activity of $6.25 \mathrm{pmol} /$ $5 \mathrm{~min}$ per $\mu \mathrm{g}$ of protein for a purified membrane preparation from the same batch of chromaffin

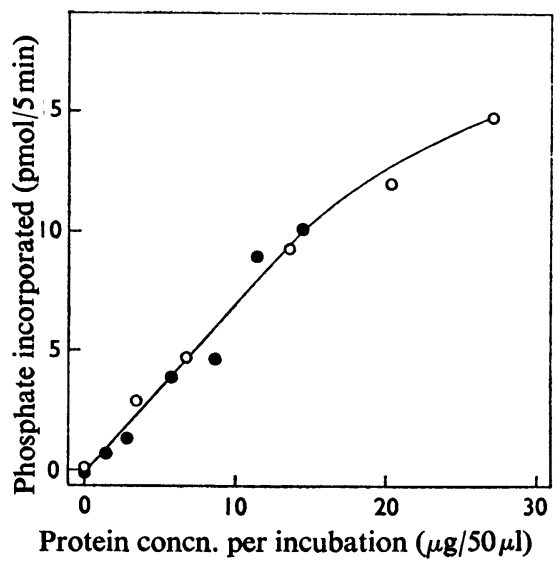

Fig. 8. Phosphorylation of lysed and intact chromaffin granules

Portions $(0.5 \mathrm{ml})$ of a suspension of the crude granule fraction were dialysed for $7 \mathrm{~h}$ in the cold, (1) against $250 \mathrm{ml}$ of $0.3 \mathrm{M}$-sucrose containing $10 \mathrm{~mm}$-Hepes, pH7.2 (iso-osmotic dialysis) (O); and (2) against $250 \mathrm{ml}$ (with four changes of solution) of $10 \mathrm{~mm}-$ Tris-HCl, pH7.5 (hypo-osmotic dialysis) (•). Samples were removed for protein, catecholamine and phosphorylation assays. No catecholamines could be detected in the lysed samples. Phosphorylation was assayed for $5 \mathrm{~min}$ at $37^{\circ} \mathrm{C}$ in iso-osmotic solution (see 'Methods', with $38 \mu \mathrm{M}-\left[\gamma-{ }^{32} \mathrm{P}\right] \mathrm{ATP}$ $\left(1.97 \times 10^{5}\right.$ c.p.m. $\left./ \mathrm{nmol}\right)$.

granules $(10-20 \%$ of the chromaffin granule protein is thought to be present in the membrane).

\section{Discussion}

Although diphosphoinositide cannot be detected as a component of chromaffin-granule membranes when isolated from the bovine adrenal medulla, it may in fact be an important component in vivo. The adrenal medulla is rich in enzymes that render the radioactive phosphate of the phosphorylated membranes acid-soluble (J. H. Phillips, unpublished work) and it is well known that brain diphosphoinositides are rapidly degraded post mortem (Dawson \& Eichberg, 1965). In view of the low content of phosphatidylserine, diphosphoinositide may make an important contribution to the surface charge of chromaffin granules in vivo. Matthews et al. (1972) have concluded that the net negative charge on the surface of granules isolated by methods similar to that used in the present work derives from the carboxyl groups of proteins and of phosphatidylserine.

Hendrickson \& Fullington (1965) and Hendrickson \& Reinertsen (1969) give association constants for 
$\mathrm{Ca}^{2+}$ and $\mathrm{Mg}^{2+}$ binding to polyphosphoinositides and phosphatidylserine. Diphosphoinositide, unlike triphosphoinositide, does not have a particularly high affinity for divalent cations, being roughly similar to phosphatidylserine. Buckley \& Hawthorne (1972), however, have correlated $\mathrm{Ca}^{2+}$ binding to erythrocyte 'ghosts' with polyphosphoinositide synthesis, and have shown that this leads to a concomitant increase in the specific activity of $\mathrm{Ca}^{2+}$-stimulated ATPase.

The enzyme activity discussed in this paper is broadly similar to the plasma membrane activity described by Hawthorne and co-workers (Kai et al., 1966; Michell et al., 1967; Harwood \& Hawthorne, 1969). Notable points of difference are the very low apparent $K_{m}$ value for ATP, the $\mathrm{pH}$ profile and the lack of inhibition by $\mathrm{NaF}$. In the present work, however, the enzyme has been studied in situ, rather than in the presence of high concentrations of exogenous phosphatidylinositol and detergent. The Arrhenius plot for the chromaffin-granule kinase (Fig. 6) is of some interest: its 'transition' temperature of $27^{\circ} \mathrm{C}$ compares with a transition temperature of $32^{\circ} \mathrm{C}$ for $\mathrm{Mg}^{2+}$-stimulated ATPase of these membranes. Replotting the results of Buckley \& Hawthorne (1972) for the phosphatidylinositol kinase of erythrocyte 'ghosts' gives a 'transition' temperature of $27^{\circ} \mathrm{C}$ for this enzyme also; the phospholipid composition of erythrocyte 'ghosts' is very different from that of chromaffin-granule membranes. Breaks in Arrhenius plots have been correlated with the physical state of the phospholipid bilayer (Raison et al., 1971). The 'transition' temperature may reflect a conformational change of the enzyme resulting from a change in lipid-protein interaction, such that there is a change in the rate constants for the rate-limiting step of the phosphorylation reaction.

Because the phosphorylation reaction is very rapid in its initial stages and requires very low concentrations of ATP, intact chromaffin granules can be phosphorylated in iso-osmotic solutions with very little lysis. The incorporated phosp hate is stable in purified granules and fairly stable even in crude granule preparations as long as supernatant enzymes are not present: this should make it possible to study the properties of phosphorylated granules in vitro.

The technical assistance of Mrs. Freda Nicholls is gratefully acknowledged. I thank Dr. H. B. Pollard for helpful discussions and for communicating research results before their publication.

\section{References}

Banks, P. (1965) Biochem. J. 95, 490-496

Blaschko, H., Firemark, H., Smith, A. D. \& Winkler, H. (1967) Biochem. J. 104, 545-549

Bray, G. A. (1960) Anal. Biochem. 1, 279-285
Buckley, J. T. \& Hawthorne, J. N. (1972) J. Biol. Chem. 247, 7218-7223

Buckley, J. T., Lefebvre, Y. A. \& Hawthorne, J. N. (1971) Biochim. Biophys. Acta 239, 517-519

Dawson, R. M. C. \& Eichberg, J. (1965) Biochem. J. 96, 634-643

Duch, D. S., Viveros, O. H. \& Kirshner, N. (1968) Biochem. Pharmacol. 17, 255-264

Folch, J., Lees, M. \& Sloane-Stanley, G. H. (1957) J. Biol. Chem. 226, 497-509

Friedman, S. \& Kaufman, S. (1965) J. Biol. Chem. 240, 4763-4773

Glynn, I. M. \& Chappell, J. B. (1964) Biochem. J. 90, 147149

Gonzalez-Sastre, F. \& Folch-Pi, J. (1968) J. Lipid Res. 9, $532-533$

Harwood, J. L. \& Hawthorne, J. N. (1969) Biochim. Biophys. Acta 171, 75-88

Hendrickson, H. S. \& Fullington, J. G. (1965) Biochemistry 4, 1599-1605

Hendrickson, H. S. \& Reinertsen, J. L. (1969) Biochemistry 8, 4855-4858

Hübscher, G. \& West, G. R. (1965) Nature (London) 205, 799-800

Kai, M., White, G. L. \& Hawthorne, J. N. (1966) Biochem. J. 101, 328-337

Kaulen, H. D. (1972) Anal. Biochem. 45, 664-667

Kirshner, N. (1962) J. Biol. Chem. 237, 2311-2317

Kirshner, N. (1972) in The Structure and Function of Nervous Tissue (Bourne, G. H. ed.), vol. 5, pp. 163-204, Academic Press, London and New York

Lowry, O. H., Rosebrough, N. J., Farr, A. L. \& Randall, R. J. (1951) J. Biol. Chem. 193, 265-275

Matthews, E. K., Evans, R. J. \& Dean, P. M. (1972) Biochem. J. 130, 825-832

McClare, C. W. F. (1971) Anal. Biochem. 39, 527-530

Meldolesi, J., Jamieson, J. D. \& Palade, G. E. (1971) J. Cell Biol. 49, 109-129

Michell, R. H., Harwood, J. L., Coleman, R. \& Hawthorne, J. N. (1967) Biochim. Biophys. Acta 144, 649-658

Poisner, A. M. \& Trifaró, J. M. (1967) Mol. Pharmacol. 3, 561-571

Post, R. L. \& Sen, A. K. (1967) Methods Enzymol. 10, 762-768

Potter, L. T. (1967) J. Pharmacol. Exp. Ther. 156, 500-506

Raison, J. K., Lyons, J. M., Mehlhorn, R. J. \& Keith, A. D. (1971) J. Biol. Chem. 246, 4036-4040

Smith, A.D. \& Winkler, H. (1967) Biochem.J.103, 480-482

Stekhoven, F. M. A. H. S., Sani, B. P. \& Sanadi, D. R. (1971) Biochim. Biophys. Acta 226, 20-32

Trifaró, J. M. \& Dworkind, J. (1971) Mol. Pharmacol. 7, 52-65

von Euler, U. S. \& Hamberg, U. (1950) Acta Physiol. Scand. 19, 74-84

Weihing, R. R., Manganiello, V. C., Chiu, R. \& Phillips, A. H. (1972) Biochemistry 11, 3128-3135

Wheeler, G. E., Coleman, R. \& Finean, J. B. (1972) Biochim. Biophys. Acta 255, 917-930

Winkler, H., Hörtnagl, H., Hörtnagel, H. \& Smith, A. D. (1970) Biochem J. 118, 303-310

Wurtman, R. J. \& Axelrod, J. (1963) Biochem. Pharmacol. 12, 1439-1441 